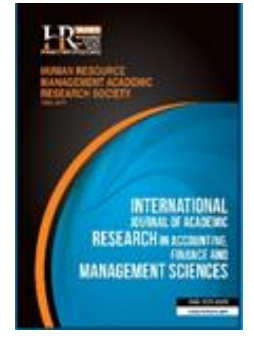

International Journal of Academic Research in Accounting, Finance and Management Sciences

Vol. 8, No.3, July 2018, pp. 118-127

E-ISSN: 2225-8329, P-ISSN: 2308-0337

(c) 2018 HRMARS

www.hrmars.com

To cite this article: Wicaksana, S.B., Asandimitra, N. (2018). Halloween Effect in Indonesia Stock Exchange, International Journal of Academic Research in Accounting, Finance and Management Sciences 8 (3): 118-127.

http://dx.doi.org/10.6007/IJARAFMS/v8-i3/4545 (DOI: 10.6007/IJARAFMS/v8-i3/4545)

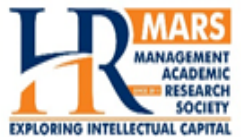

\title{
Halloween Effect in Indonesia Stock Exchange
}

\author{
Satria Bagus WICAKSANA ${ }^{1}$, Nadia ASANDIMITRA ${ }^{2}$ \\ ${ }^{1,2}$ Department of Management, Faculty of Economics, Universitas Negeri Surabaya, Indonesia, \\ ${ }^{1}$ E-mail: 9a06satria@gmail.com, ${ }^{2} E$-mail: nadiaharyono@unesa.ac.id
}

Abstract

This Halloween effect research aims to discover whether Halloween Effect as seasonal anomaly gives investors an opportunity to obtain abnormal return in Indonesia Stock Exchange. Halloween Effect theory suggests investor to buy stock in the period of November to April and get out of the market in the other month. Dzahabarov \& Ziemba (2016), Maria Caporale \& Plastun (2016) support the existence of this anomaly. In this study the sample used is the daily closing price of IHSG period 2011-2017. The variables used in this study are return, expected return, and abnormal return. Return and expected return are used to find abnormal return. This abnormal return will be used to test whether there is a difference between returns in the Halloween and Non-Halloween periods. This study uses t-test to find the difference of abnormal return between periods. The results of this study indicate that the stock market in Indonesia stock exchange does not give different abnormal return in each period.

Key words Halloween Effect, abnormal return, seasonal anomaly, Sell in May and Go Away

Received: 10 Sept 2018 (c) The Authors 2018

Revised: 28 Sept 2018 Published by Human Resource Management Academic Research Society (www.hrmars.com)

Accepted: 02 Oct 2018 This article is published under the Creative Commons Attribution (CC BY 4.0) license. Anyone may Published Online: $\quad 2018$ reproduce, distribute, translate and create derivative works of this article (for both commercial and noncommercial purposes), subject to full attribution to the original publication and authors. The full terms of this license may be seen at: http://creativecommons.org/licences/by/4.0/legalcode

\section{Introduction}

This study will examine a monthly anomaly called Halloween Effect which is also often known as Sell in May and Go Away. Sell in May is a strategy that is quite popular abroad that suggest investors to sell their assets (shares) in the period from May to November in order to avoid falling prices on the market. In Indonesia, the theory and the In May Sell period are quite relevant for researchers. This is because during this period there were several national holidays and school holidays which were generally used by the people to get a break from their habit. These break activities which take place during holidays, can be a reason for investors to withdraw their money from stock market. When investors withdraw their money, trading intensity will also decrease. On the other hand there will be a selling phenomenon, because there are many investors who want to make a vacation.

Regarding Sell In May, Haggard and Witte (2010) examined the return of shares related to Sell In May and Go Away. This study found that stock earnings from November to April were higher than other months. This anomaly is known as "Halloween Effect" and the results of this study are the emergence of rules: selling shares in early May, then investing in T-bills (short-term bonds), and in the end investment returns to stock after Halloween.

Dichtl and Drobetz (2013) in his research stated "The old and simple investment strategy" Sell in May and Go Away "(also referred to as" Halloween Effect ") enjoys an unbroken popularity". This sentence confirms that "Halloween Effect" and Sell in May and Go Away are the same events. Dichtl and Drobetz (2013) also examined Sell in May and Go Away. This research uses a regression model and also a "Superior Predictive Ability" test to analyze whether the stock market is really inefficient, in line with predictions of 
market efficiency. This research creates the conclusion that the existence of "Halloween Effect" has begun to fade and even disappear. This result was even reinforced by Hansen (2005) "Superior Predictive Ability" test which resulted in the conclusion that "Halloween Effect" never gave the opportunity to obtain a profit that was statistically significant compared to the buy-hold benchmark method.

Like other commodities, stock prices also fluctuate. Fluctuations that occur in the stock market are the reason for traders to buy and sell shares for profit. However, being a trader meaning more time going to be needed for analyzing stock that going to be trade. Because, to take a buy and/or sell position, a trader needs to analyze his demand and supply, the current and previous trading volume conditions, news, and various other specific sides. The many things that traders need to know, consider, and supervise, do not become stopper of Indonesian trader growth. This is evidenced by the high volume of stock trading on the Indonesian stock exchange, which can be indirectly interpreted as the transfer of share ownership.

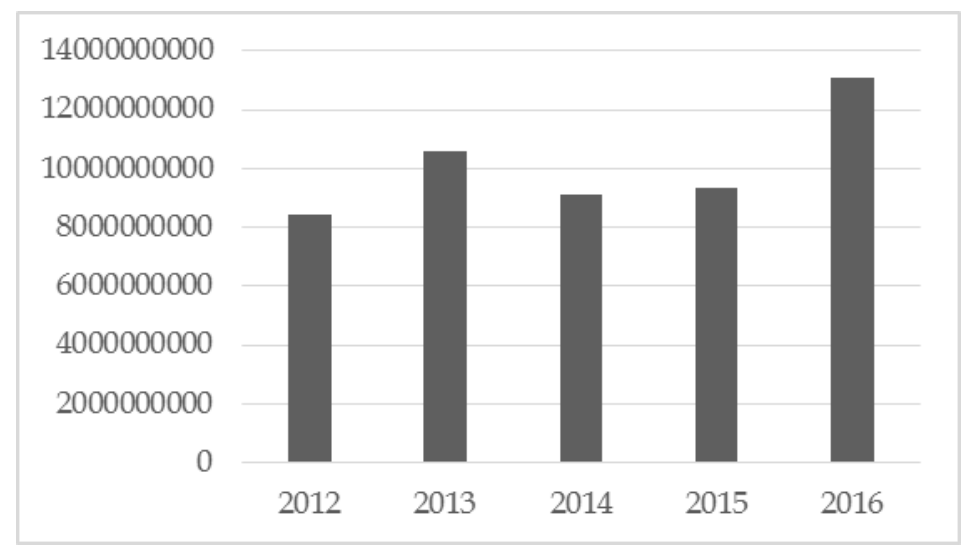

Figure 1. Trade Volume Year on Year

\section{Theoretical Framework and Hypothesis Development}

\subsection{Efficient Market Concept}

The concept of efficient markets was first described and popularized by Fama (1969). The market that is meant by Fama is a capital market and money market which is also used for financial investment. The level of efficiency has been achieved by a market if abnormal returns are not obtained by every investor in the market. It can be interpreted that the prices of all products in the market have reflected all available information. From this information it can be assumed that asset prices in the market quickly reflect information that arises from these assets.

\subsection{Efficient Market Form}

The most important key in measuring the level of market efficiency is through the linkage between the price of securities and information Hartono (2013). According to Fama (1969) the efficient form market is grouped into three categories, (1) weak form of the efficient market hypothesis, (2) semi-strong form, and strong form. The level of information absorption in the market can be a reference for which efficient market forms are suitable for the market

a. Weak Form Efficient Market Hypothesis (Weak Form)

In a weak form efficient market, current prices cannot be predicted using past values because they have been fully reflected.

b. Semi-Strong Form Efficient Market Hypothesis (Semi-Strong Form)

The market can be classified into a semi-strong efficient type if the security price has fully reflected the entire publicly available information, including information derived from technical analysis and the results of fundamental analysis.

c. Strong Form Efficient Market Hypothesis (Strong Form)

The market is categorized as efficient in strong form if the price is fully reflecting all the available information including information from the internal company. 


\subsection{Market Anomaly}

Discussions related to testing market efficiency cannot be separated from the discussion of the existence of irregularities (anomalies) related to the efficient market hypothesis. Jones (1997) states that anomalies are strategies or techniques that is not in line with the concept of efficient markets. Anomalies cause structured and/or scrambled market movements in specific periods. Market anomalies can cause the stock return build a pattern that investor are able to read and use to obtain a higher abnormal return.

Market anomalies classifies into four types based on the characteristics of events namely (1) firm anomalies (firm anomaly), seasonal anomalies (seasonal anomalies), event anomalies (anomaly events), and accounting anomalies (accounting anomaly). According to Oprea and Tilica (2014) there are three variations of the seasonal anomaly, Monday effect states that Monday's returns are, in general, negative and lower than those on Tuesday through Friday; The weekend effect suggests that there is a significant difference between returns on Monday and returns on Friday and the day-of-the-week (DOW) effect the returns on some day of the week are substantially different than the returns on other days of the week. But one of the most exciting anomalies is the Halloween effect (Oprea,2014).

\subsection{Halloween Effect}

Regarding Sell in May, Haggard and Witte (2010) examined the returns on related shares Sell In May and Go Away. This study found that stock earnings from November to April were higher than other months. This anomaly is known as "Halloween Effect" and the results of this study are emerging rules: selling shares at the beginning of May, investing in T-bills (short-term bonds), and investing back in stock after Halloween. This study uses the $T$ test with regression with dummy.

Dichtl and Drobetz (2013) in his study stated "The old and simple investment strategy" Sell in May and Go Away "(also referred to as" Halloween Effect ") enjoys an unbroken popularity. In this sentence confirm that" Halloween Effect "and Sell in May and Go Away are the same events. At that paper Dichtl and Drobetz (2013) also examined Sell In May and Go Away. This research uses a regression model and also Hansen (2005) "Superior Predictive Ability" tests to analyze whether the stock market is truly inefficient, in line with predictions of market efficiency. This research creates the conclusion that the existence of "Halloween Effect" has begun to fade and even disappear. This result was even reinforced by Hansen (2005) "Superior Predictive Ability" test which resulted in the conclusion that "Halloween Effect" never gave the opportunity to obtain a profit that was statistically significant compared to the buy-hold benchmark method.

\subsection{Stock Return}

Return is the result or income derived from investment activities. Return can be the realization of past events or expectation returns that have not yet occurred but are expected to occur in the future Hartono (2014). There is two type of invest income.

1. Realized Return or Actual Return

Actual return is a return that has been realized. Historical data is used to calculate Actual return. Actual return is important because it is used as a reference for company performance. Actual return can also be used as a basis for determining expected returns and risks in the future.

$$
\mathrm{R}_{\mathrm{it}}=\frac{\mathrm{P}_{\mathrm{t}}-\mathrm{P}_{\mathrm{t}-1}}{\mathrm{P}_{\mathrm{t}-1}}
$$

Where:

Rit: real return (actual return);

Pt: period t securities price;

Pt-1: t-1 period security price.

\section{Expected Return}

Expected return is the return predicted by investors in the future. Unlike the actual return which is the return that has occurred / obtained, the expected return has not occurred. 
The expected return equation is calculated by the formula:

$$
\mathrm{E}(\mathrm{R})=\sum_{i=1}^{n} \mathrm{Ri} . \text { pri }
$$

Where:

$E(R)$ : expected return from a security;

Ri: i return that might occur;

pri: probability of return occurrence i;

$\mathrm{N}$ : the number of possible returns.

\subsection{Abnormal Return Saham}

Abnormal returns are the result of reducing actual return to the expected return, or the difference between the return that has been received and Hartono (2014) expectation return. Abnormal return does not have to be positive or in the form of profit but can also appear in the form of a negative value loss (Fitriyani, 2013). Calculation of abnormal returns is as follows:

$$
A R i, t=R i, t-E[R i, t]
$$

Where:

Ari, $t$ : abnormal returns of securities " $i$ " in the event period of " $t$ ";

$\mathrm{Ri}, \mathrm{t}$ : actual return that occurs for the i securities in the t period;

$E[R i, t]$ : expected return of the i-security for the t-event period.

\subsection{Expected Return}

Calculating the expected return can use estimation models mean-adjusted model, market model, and market-adjusted model.

a. Mean-adjusted model

This mean-adjusted model assumes that the expected return is constant value that equal to the average of previous actual return during the estimation period, as follows:

$\mathrm{E}[\mathrm{Ri}, \mathrm{t}]=\frac{\sum_{j=t 1}^{t 2} R \mathrm{i}, \mathrm{j}}{T}$

Where:

$E[R i, t]$ : expected return of the securities in the event period $t$;

$\mathrm{Ri}, \mathrm{j}$ : actual return of I security in the $\mathrm{j}$ period;

$\mathrm{T}$ : the length of the estimation period, which is from $\mathrm{t} 1 \mathrm{to} \mathrm{t} 2$.

b. Market model

Expectation calculations with market models are carried out in two stages, (1) forming an expectation model with realization data during the estimation period and (2) using this expectation model to predict the expected return in the window period. Expectation model can be formed using OLS (Ordinary Least Square) regression technique with the equation:

$R i, t=\sigma i+\beta i . R M t+\varepsilon i, j r$

Where:

$\mathrm{Ri}, \mathrm{t}$ : actual return i-security in the t period;

$\sigma i$ intercept for i-securities;

$\beta i$ : slope coefficient which is a beta of i-security;

RMt: return market index in the $t$ period which can be calculated by the formula:

RMT = (IHSGt - IHSGt-1)

Where:

$\varepsilon i$, t: the error of the 1st securities residual in the t period;

c. Market-adjusted model. 
Market adjusted models assume that the best variable to estimate securities returns is the market index at that time. With this model, it is no longer necessary to use the estimation period to develop an estimation model, because the expectation of securities return is the same as the market index return.

This study uses a market-adjusted model because this method is considered easier and more precise than other models. Market-adjusted models follow market prices and do not require determining the estimated period. This model can be calculated by the following formula:

$\mathrm{Ri}, \mathrm{t}=\mathrm{Rm}, \mathrm{t}$

Where:

$\mathrm{Ri}, \mathrm{t}$ : actual return index $\mathrm{i}$ in the event period $\mathrm{t}$;

$\mathrm{Rm}, \mathrm{t} \quad$ : market return in the t-estimation period where:

$\mathrm{Rm} \cdot \mathrm{t}=\mathrm{SB}_{\mathrm{t}}$

Where:

Rm.t: market return in period t;

SBt: Period t interest rate.

Based on background, theoretical basis and previous research framework, the hypothesis of this study is: There is a difference in the return of the Halloween Effect with other months on the JCl on the Indonesia Stock Exchange for the 2011-2017 period.

\section{Methodology of research}

\subsection{Types of Research}

This study is categorized as event study research because it examines market reactions as indicated by the acquisition of abnormal returns to the existence of a Halloween Effect event. Event study is a study of observing reactions from the market due to an event (event) whose information is published in form of announcement. Event studies can be used as a reference to find out information content in a publication and can also be used to assess semi-strong market efficiency Hartono (2014). Event study studies to how fast a published information in the market can affect the rise or fall of the price of securities Tandelilin (2001).

\subsection{Research Resources and Data}

The data source used in this study is secondary data. According to Kuncoro (2009) secondary data has generally been collected by data search agencies and distributed to data users. Data sources obtained indirectly have been published and are known to come from the daily IHSG closing price report from May 2011 - April 2018 sourced from the closing price history on Yahoo Finance and the Indonesia Stock Exchange (BEI) Report. Population, in this study is the IHSG daily closing price for the period 2011-2018. Closing price data is taken with documentation techniques. Closing price data is taken because the closing price reflects the price of the last transaction that occurred on the exchange. The research sampling technique used in this research is saturated sampling. According to Sugiyono (2012), that saturated sampling technique is a sample determination technique if all parts of the population are used as research samples.

\subsection{Data Analysis Technique}

The steps in the Halloween Effect analysis are:

a. Determining data collection periods during Sell In May. The research period used is 2011-2018.

Table 1. Month Cluster of Observation

\begin{tabular}{|l|l|}
\hline \multicolumn{1}{|c|}{ Month } & \multicolumn{1}{c|}{ Month Cluster } \\
\hline May $(\mathrm{t})$ & Halloween Effect \\
\hline June $(\mathrm{t})$ & Halloween Effect \\
\hline July $(\mathrm{t})$ & Halloween Effect \\
\hline August $(\mathrm{t})$ & Halloween Effect \\
\hline
\end{tabular}




\begin{tabular}{|l|l|}
\hline \multicolumn{1}{|c|}{ Month } & \multicolumn{1}{c|}{ Month Cluster } \\
\hline September $(t)$ & Halloween Effect \\
\hline October $(t)$ & Halloween Effect \\
\hline November $(t)$ & Non Halloween Effect \\
\hline December $(t)$ & Non Halloween Effect \\
\hline January $(t+1)$ & Non Halloween Effect \\
\hline February $(t+1)$ & Non Halloween Effect \\
\hline March $(t+1)$ & Non Halloween Effect \\
\hline April $(t+1)$ & Non Halloween Effect \\
\hline
\end{tabular}

b. Collect data on the Composite Stock Price Index (daily) at the close of trading. during the period 2011-2018.

c. Calculate the actual return (Rit) of the $\mathrm{JCl}$ that was examined during the study period by using stock price data at the close of trading every day. With the formula:

(Rit) $=$ Rt - Rt-1

d. Determine the expected return with a reference to the Bank Indonesia interest rate.

e. Calculate abnormal returns of each company stock during the study period. According to Hartono (2014) the formula for calculating abnormal returns is as follows.

$A R i, t=R i, t-E[R i, t]$

f.Calculate the AAR (average abnormal return) of the $\mathrm{JCl}$ for each group of months during the observation period with the following formula:

$$
\operatorname{AAR}_{\mathrm{t} 1, \mathrm{tp}}=\frac{\Sigma_{\mathrm{t}=\mathrm{t} 1}^{\mathrm{Tp}} \mathrm{AR \textrm {i } , \mathrm { t }}}{\mathrm{N}}
$$

Where:

AARt1tp: average abnormal return (average abnormal return) from day t1 to day $t p$;

Ari,t: abnormal return (accumulative abnormal return) of the 1st securities from day t1 to day tp;

$\mathrm{N}$ : number of days.

g. Perform normality test to research data, to find out methods or ways to test different research data.

h. If the data is not normal, then Kruskal Wallis test is conducted to test the difference between two independent variables that do not meet the assumption of normality.

i. If the data is normal, then statistical testing is done with statistical analysis tools Average difference test (t-test) using the help of SPPS version 20. This test is done on the value of an observation based on a sample of a population so that it uses one sample test. This test is used to see whether there are differences in abnormal returns in the study sample during the observation period. The following stages of testing:

j. Formulating Hypotheses

H0: There is no difference in the return of the Halloween Effect month with other months on the Indonesia Stock Exchange for the 2011-2017 period.

$\mathrm{Ha}$ : There is a difference in the return of the Halloween Effect with other months on the $\mathrm{JCl}$ on the Indonesia Stock Exchange for the 2011-2017 period.

k. Test hypotheses using different test techniques, two paired samples, namely Paired Sample t-test because the sample group for calculating the Halloween Effect and other months. This research is included in the non-parametric type, so it does not require data normality testing. So that after the data collection is done, the hypothesis can be tested immediately.

Tests were carried out in groups in May, June, July, August, September, October with groups in January, February, March, April, November, December. The steps in this test are:

a) Determine the level of significance $(\alpha)$, which is $5 \%$ with the degree of freedom (df) of $n-1$.

b) Comparing the probability (p) of t-count with $\alpha$ of $5 \%$.

c) The drawing of conclusions in this test is based on: 
a. If the probability value $(p)<0.05$ then $\mathrm{Ho}$ is rejected.

b. If the probability value $(p)>0.05$ then Ho is accepted.

I. Based on the existing test results, if $\mathrm{Ha}$ is accepted and $\mathrm{HO}$ is rejected then there is a difference in the return of the May period, June, July, August, September, October with the January, February, March, April, November, December periods. If $\mathrm{HO}$ is accepted and $\mathrm{Ha}$ is rejected then there is no difference in the return of the May period, June, July, August, September, October with January, February, March, April, November, December. If there are differences in returns between May, June, July, August, September, October with other months, it can be concluded that Halloween Effect occurred.

\section{Results}

\subsection{Research Result}

After calculating the average abnormal return, the next step is to do a different test to see the difference in abnormal returns in the study sample during the observation period. Normality tests need to be carried out before different tests can be carried out. This is because the method that will be used to test the difference between normal and abnormal samples is not the same. The T test can be used if the sample data is normal. However, if the data is not normal then the testing method is different using the Kruskall Wallis method.

\begin{tabular}{|c|c|c|c|c|c|c|}
\hline \multicolumn{7}{|c|}{ One-Sample K } \\
\hline & & & h2017 & nh2017 & h2016 & nh2016 \\
\hline $\bar{N}$ & & & 6 & 6 & 6 & 6 \\
\hline \multirow[t]{2}{*}{ Normal Parameters ${ }^{a, b}$} & Mean & & 2,9001650 & 2,3607800 & 4,9295833 & 2,5966533 \\
\hline & Std. Deviation & & 2,18358725 & 15,84880423 & 5,91166750 & 7,84875240 \\
\hline \multirow[t]{3}{*}{ Most Extreme Differences } & Absolute & & 178 & .230 & .178 & .278 \\
\hline & Positive & & 178 & .147 & .175 & .238 \\
\hline & Negative & & -.135 & -.230 & -.178 & -.278 \\
\hline Kolmogorov-Smirnov Z & & & .436 & .564 & .437 & 682 \\
\hline Asymp. Sig. (2-tailed) & & & 991 & .908 & .991 & .741 \\
\hline \multirow[t]{3}{*}{ Monte Carlo Sig. (2-tailed) } & Sig. & & $.975^{\circ}$ & $.846^{\circ}$ & $.975^{\circ}$ & $.652^{\circ}$ \\
\hline & $95 \%$ Confidence Interval & Lower Bound & .972 & .839 & .972 & 643 \\
\hline & & Upper Bound & 978 & .853 & .978 & 662 \\
\hline
\end{tabular}

Figure 2. One Sample Kolmogorov-Smirnov Test 2017-2016

\begin{tabular}{|c|c|c|c|c|c|c|}
\hline \multicolumn{7}{|c|}{ One-Sample Kolmogorov-Smirnov Test } \\
\hline & & & h2015 & nh2015 & h2014 & nh2014 \\
\hline $\mathrm{N}$ & & & 6 & 6 & 6 & 6 \\
\hline \multirow{2}{*}{ Normal Parameters ${ }^{\mathrm{a}, \mathrm{b}}$} & Mean & & $-5,1808167$ & .0559833 & 2,3101500 & 2,6745667 \\
\hline & Std. Deviation & & 11,44332737 & 10,38416069 & 4,93165509 & 8,23874221 \\
\hline \multirow[t]{3}{*}{ Most Extreme Differences } & Absolute & & .272 & .440 & .284 & .247 \\
\hline & Positive & & .272 & .211 & .284 & .188 \\
\hline & Negative & & -202 & -.440 & -.182 & -.247 \\
\hline Kolmogorov-Smirnov Z & & & .665 & 1.079 & .695 & .604 \\
\hline Asymp. Sig. (2-tailed) & & & .768 & .195 & .720 & .858 \\
\hline \multirow[t]{3}{*}{ Monte Carlo Sig. (2-tailed) } & Sig. & & $.674^{\circ}$ & $.135^{\circ}$ & $.618^{\circ}$ & $.780^{\circ}$ \\
\hline & $95 \%$ Confidence Interval & Lower Bound & .665 & .129 & .608 & .771 \\
\hline & & Upper Bound & 683 & .142 & .627 & .788 \\
\hline
\end{tabular}

Figure 3. One Sample Kolmogorov-Smirnov Test 2015-2014

\begin{tabular}{|c|c|c|c|c|c|c|}
\hline \multicolumn{7}{|c|}{ One-Sample Kolmogorov-Smirnov Test } \\
\hline & & & h2013 & nh2013 & h2012 & nh2012 \\
\hline \multirow{3}{*}{ Normal Parameters ${ }^{\mathrm{a}, \mathrm{b}}$} & & & 6 & 6 & 6 & 6 \\
\hline & Mean & & $-5,0679333$ & 3,8833500 & 1,1973167 & 5,6192500 \\
\hline & Std. Deviation & & 12,83019635 & 9,81604124 & 10,08201170 & 6,87905197 \\
\hline \multirow[t]{3}{*}{ Most Extreme Differences } & Absolute & & .197 & .213 & .272 & .221 \\
\hline & Positive & & .133 & .187 & .189 & .221 \\
\hline & Negative & & -197 & -.213 & -.272 & -.144 \\
\hline Kolmogorov-Smirnov Z & & & .481 & .521 & .667 & .542 \\
\hline Asymp. Sig. (2-tailed) & & & .975 & .949 & .766 & .930 \\
\hline \multirow[t]{3}{*}{ Monte Carlo Sig. (2-tailed) } & Sig. & & $.938^{\circ}$ & $.898^{\circ}$ & $.677^{\circ}$ & 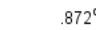 \\
\hline & 95\% Confidence Interval & Lower Bound & .933 & .892 & .668 & .865 \\
\hline & & Upper Bound & .943 & .904 & .686 & .878 \\
\hline
\end{tabular}

Figure 4. One Sample Kolmogorov-Smirnov Test 2013-2012 


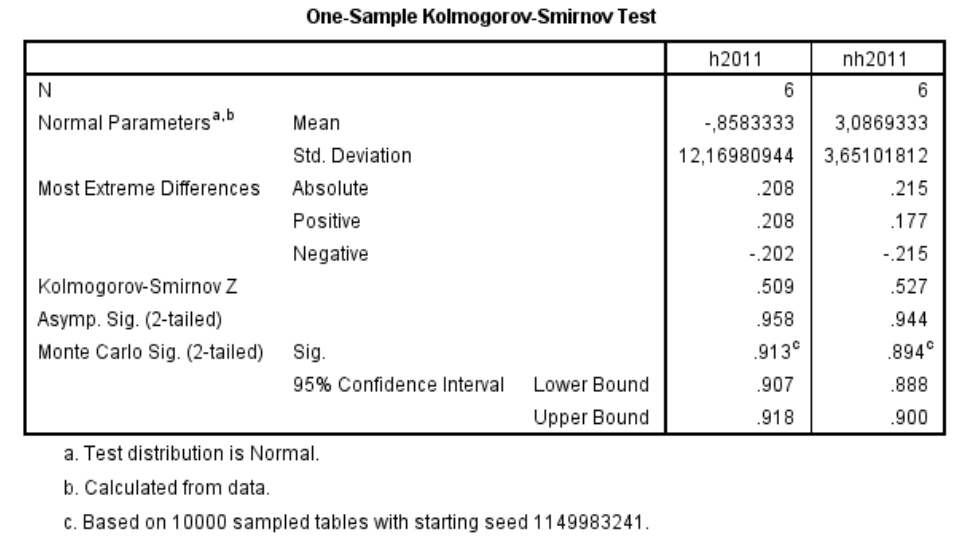

Figure 5. One Sample Kolmogorov-Smirnov Test 2011

The test used to find out whether the sample data is normally distributed is the Kolmogorov Smirnov one-sample test. The results of the Kolmogorov Smirnov one-sample test were found that the absolute value of the entire sample was under Kolmogorov table and asymp Sig. (2-tailed) above 0.05. So it can be concluded that the entire sample data is normally distributed

\subsection{Hypothesis testing}

Hypothesis testing used in this study is a different test of two paired samples namely paired sample ttest because the sample group for calculating the period of the Halloween month and other months outside Halloween has the same number of members and comes from the same population. The test was carried out by forming two testing pairs namely in the Halloween period period with the non-Halloween month period. Here is the research hypothesis in this test.

HO: There is no difference in the abnormal return of the Halloween Effect with other months on the $\mathrm{JCl}$ on the Indonesia Stock Exchange for the 2011-2017 period

$\mathrm{Ha}$ : There is a difference in the abnormal return of the Halloween Effect with other months on the JCl on the Indonesia Stock Exchange for the 2011-2017 period.

Table 2. Paired Samples Test Result

Paired Samples Test

\begin{tabular}{|c|c|c|c|c|c|c|c|c|c|}
\hline & & \multicolumn{5}{|c|}{ Paired Differences } & \multirow[b]{3}{*}{$t$} & \multirow[b]{3}{*}{ df } & \multirow[b]{3}{*}{ Sig. (2-tailed) } \\
\hline & & \multirow[b]{2}{*}{ Mean } & \multirow[b]{2}{*}{ Std. Deviation } & \multirow{2}{*}{$\begin{array}{l}\text { Std. Error } \\
\text { Mean }\end{array}$} & \multicolumn{2}{|c|}{$\begin{array}{l}\text { 95\% Confidence Interval of the } \\
\text { Difference }\end{array}$} & & & \\
\hline & & & & & Lower & Upper & & & \\
\hline Pair 1 & h2017 - nh2017 &, 53938500 & 15,50071009 & 6,32813840 & $-15,72761261$ & 16,80638261 & .085 & 5 & .935 \\
\hline Pair 2 & h2016-nh2016 & 2,33293000 & 8,06901629 & 3,29416211 & $-6,13498327$ & 10,80084327 & .708 & 5 & .510 \\
\hline Pair 3 & h2015 - nh2015 & $-5,23680000$ & 18,87170685 & 7,70434206 & $-25,04144175$ & 14,56784175 & -.680 & 5 & .527 \\
\hline Pair 4 & h2014 - nh2014 &,- 36441667 & 6,41956819 & 2,62077774 & $-7,10134032$ & 6,37250699 & -.139 & 5 & .895 \\
\hline Pair 5 & h2013 - nh2013 & $-8,95128333$ & 19,85936184 & 8,10755052 & $-29,79240543$ & 11,88983876 & -1.104 & 5 & .320 \\
\hline Pair 6 & h2012-nh2012 & $-4,42193333$ & 11,23582046 & 4,58700449 & $-16,21320377$ & 7,36933710 & -.964 & 5 & .379 \\
\hline Pair 7 & h2011 - nh2011 & $-3,94526667$ & 14,87657480 & 6,07333623 & $-19,55727446$ & 11,66674113 & -.650 & 5 & .545 \\
\hline
\end{tabular}

Based on table 4.8 Indicates that the results of the abnormal return test for the Halloween period with non-Halloween groups have a range of Sig. (2-tailed) 0.824 to 0.754 which means above the significance level of 0.05 . This shows that $\mathrm{Ho}$ is accepted which means that there is no difference in abnormal returns for Halloween with other months on the $\mathrm{JCl}$ on the Indonesia Stock Exchange for the period 2011-2018. 


\section{Discussions and conclusions}

\subsection{Discussions}

The results of the t-test showed that there was no difference in abnormal returns between the Halloween Effect and non-Halloween Effect periods in the Composite Stock Price Index on the Indonesia Stock Exchange for the 2011-2018 period. So the results of this study state that there is no difference in the abnormal return of the Halloween Effect period with other months in the Composite Stock Price Index on the Indonesia Stock Exchange for the 2011-2017 period. This condition shows that the capital market does not react positively to the Halloween Effect period. This is because investors consider the Halloween Effect period is not an important moment or good news because Indonesian culture itself does not celebrate Halloween. The application of the sell strategy in may and go away as another name for Halloween Effect also does not need to be applied in Indonesia because the abnormal return of the Composite Stock Price Index does not differ in the period of the anomaly.

The results of this study support the research conducted by Dichtl and Drobetz (2014) which states that Halloween Effect has actually weakened over time. In addition, currently people are giving less attention to their secondary needs. Currently money or profits are preferred. With such a situation people followed the same business routine during the Halloween Effect so that the capital market activities remained the same during the Halloween Effect with other months outside the Halloween Effect in one year. Zhang and Jacobsen (2012) research also supports the results of this study which shows that this monthly phenomenon is only an illusion of investors.

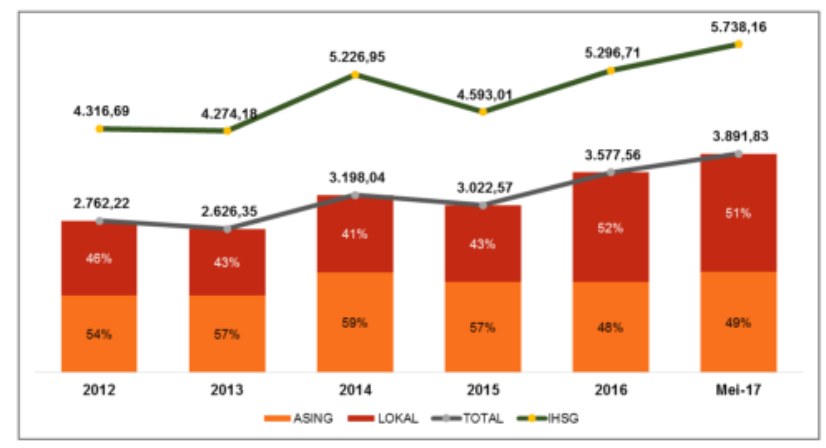

Figure 6. Local and Foreign Capitalization On Jakartas Composite Index

The absence of Halloween Effect anomalies in the 2016-2017 period in Indonesia is possible because the number of shareholdings in the Indonesian capital market that are not too much different between foreign and local ownership (Figure 4.1). Even the position of local ownership has exceeded the number of foreign ownership. However, in 2012 to 2015 when foreigners still had a dominant position on the JCl, the Halloween Effect phenomenon remained undiscovered. The absence of the Halloween Effect phenomenon is because Halloween Effect is not a special period so it does not affect the pattern of investment in the $\mathrm{JCl}$.

Another factor that can cause absence of Halloween Effect on the $\mathrm{JCl}$ is the low number of local and retail investors in the stock market compared to the number of population in Indonesia. The small number of local and retail investors can't causes a high level of volatility in the $\mathrm{JCI}$. Many special days like national holiday in the Halloween period still can't lead to withdrawal of funds from the capital market by retail investors. One of the longest holiday is when the changes of school term holiday. These special days are in the Halloween Effect period and still can't affect the investment pattern of retail investors especially those who have a family or have children. This study concludes that Halloween effect does not occur in Indonesia, and from each period cannot give a significant difference between one another. Investors still have to analyze the market and look for positive news to make a profit, and avoid negative news to avoid losses in investing in the capital market.

\subsection{Conclusions}

Based on the results of the research and discussion, it can be concluded that there is no difference in the return of Halloween and non-Halloween on the JCl on the IDX for the 2011-2017 period. So that shows 
the absence of Halloween Effect in the $\mathrm{JCl}$ during the study period. Based on the research conducted and the conclusions obtained, the researcher submits the following suggestions.

1. For Issuers

Issuers do not need to consider specific publications in the Halloween period because this phenomenon does not occur, but issuers must maintain their companies so as not to cause negative corporate actions.

2. For Investors

Investors need to do an analysis before deciding to make an investment that is by understanding and anticipating the occurrence of events that contain positive information as good news or negative information as bad news. So as to obtain benefits that are in line with their expectations, investors not only focus on an event but also anticipate other events that can influence the changes in stock prices and pay attention to macroeconomic conditions to anticipate a certain event on an economic condition.

3. For Further Researchers

a. Examining Halloween Effect by using other abnormal return calculation models, namely the mean adjusted model or market model.

b. Subsequent research is expected to include calculation of Trading Volume Activity in the test. The addition of these calculations is expected to provide a more explanation of the market reaction to the Halloween Effect event.

\section{References}

1. Dichtl, H., \& Drobetz, W. (2013). Are stock markets really so inefficient? The case of the "Halloween Indicator." Finance Research Letters, 11(2), 112-121. https://doi.org/10.1016/j.frl.2013.10.001

2. Dichtl, H., \& Drobetz, W. (2014). Sell in May and Go Away: Still good advice for investors? International Review of Financial Analysis, 38, 29-43. https://doi.org/10.1016/j.irfa.2014.09.007

3. Fama, E. F. (1969). American Finance Association Efficient Capital Markets : A Review of Theory and Empirical Work. The Journal of Finance, 25(2), 28-30.

4. Haggard, K. S., \& Witte, H. D. (2010). The Halloween effect: Trick or treat? International Review of Financial Analysis, 19(5), 379-387. https://doi.org/10.1016/j.irfa.2010.10.001

5. Hartono, J. (2013). Teori Portofolio dan Analisis Investasi, Edisi Kedelapan. BPFE Fakultas Ekonomika dan Bisnis UGM.

6. Hartono, J. (2014). Teori Portofolio dan Analisis Investasi. Yogyakarta: BPFE-Yogyakarta.

7. Jones, C. P. (1997). Investments: Analysis and Management. New York: John Wiley \& Sons, Inc.

8. Kuncoro, M. (2009). Metode Riset untuk Bisnis \& Ekonomi (3rd ed.). Jakarta: Erlangga.

9. Oprea,D.S. (2014) The Halloweeb Effect: Evidence from Romania. International Journal of Academic Research in Business and Social Sciences. 4(7). 463-471

10.Oprea,D.S.\& Tilica, E.V. (2014). Day-of-the Week Effect on Post Communist East European Stock Markets.International Journal of Academic Research in Accounting, Finance and Management Sciences.4(3), 119-129.

11.Sugiyono. (2012). Memahami Penelitian Kualitatif. Bandung: Alfabeta.

12.Tandelilin, E. (2001). Analisis Investasi dan Manajemen Portofolio Edisi Pertama. Yogyakarta: BPFE-Yogyakarta.

13.Zhang, C. Y., \& Jacobsen, B. (2012). Are monthly seasonals real? A three century perspective. Review of Finance, 17(5), 1743-1785. https://doi.org/10.1093/rof/rfs035 